\title{
Isolation and Thermal Stabilization of Bacteriocin Nisin Derived from Whey for Antimicrobial Modifications of Polymers
}

\author{
Pavlina Holcapkova, ${ }^{1}$ Zuzana Kolarova Raskova, ${ }^{1}$ Martina Hrabalikova, \\ Alexandra Salakova, ${ }^{2}$ Jan Drbohlav, ${ }^{2}$ and Vladimir Sedlarik ${ }^{1}$ \\ ${ }^{1}$ Centre of Polymer Systems, University Institute, Tomas Bata University in Zlin, Tr. T. Bati 5678, 76001 Zlin, Czech Republic \\ ${ }^{2}$ Dairy Research Institute, Ke Dvoru 12a, 16000 Prague 6, Czech Republic \\ Correspondence should be addressed to Vladimir Sedlarik; sedlarik@ft.utb.cz
}

Received 19 July 2017; Revised 7 October 2017; Accepted 23 October 2017; Published 14 November 2017

Academic Editor: Marc Behl

Copyright (C) 2017 Pavlina Holcapkova et al. This is an open access article distributed under the Creative Commons Attribution License, which permits unrestricted use, distribution, and reproduction in any medium, provided the original work is properly cited.

This work describes novel alternative for extraction of bacteriocin nisin from a whey fermentation media and its stabilization by using polyethylene glycol as matrix with high practical applicability. This product was compared with commercially available nisin product stabilized by sodium chloride and nisin extracted and stabilized by using ammonium sulfate and polysorbate 80 . The stability of samples was tested by means of long-term storage at $-18,4,25$, and $55^{\circ} \mathrm{C}$ up to 165 days. The nisin content in the samples was determined by high-performance liquid chromatography and electrophoresis. In addition, effect of whey fortification with lactose on nisin production and antibacterial activity studied against Staphylococcus aureus was tested. Results show that stabilization by polyethylene glycol provides enhanced nisin activity at $55^{\circ} \mathrm{C}$ after 14 days and long-term stability at $25^{\circ} \mathrm{C}$ with keeping antibacterial activity.

\section{Introduction}

Nisin is a water-soluble polycyclic aromatic peptide possessing excellent antibacterial properties against Gram-positive bacterial strains [1]. The bacteriocin that belongs to the group of lantibiotics, in several variants differing in amino acid sequence in their structures, is produced by bacterial strains possessing specific genome. The bacteriocins are designated nisin A, nisin Z, nisin Q, F nisin (Lactococcus lactis), and nisin U (Streptococcus uberis) [2-6]. Recently, nisin $H$ variant produced by Streptococcus hyointestinalis was described by O'Connor et al. [7].

Nisin belongs to the first described bacteriocins and it was recognized as a biological safe food preservative by Food and Agriculture Organization of the United Nations and World Health Organization already in 1968 [8]. It is produced biotechnologically through fermentation of a substrate such as whey or milk by the bacterial strains mentioned above [9].

Since there has been growing scientific and industrial interest in naturally occurring antimicrobial compounds that can be used for effective antimicrobial modifications of polymers, nisin is the ideal modifier showing antimicrobial activity at low concentrations that predetermine its application in food packaging, cosmetics and/or medical devices production. In addition, legislative requirements for introduction of nisin modified polymer system on the market could be significantly lower since it is considered to be a safe compound [8].

Since the nisin stability is limited, utilization of stabilizers is necessary to prolong its activity. Further additives improving its stability are used. The commercially available nisin is usually produced, concentrated, and processed into a powder containing over $90 \%$ of the stabilizer salt, especially sodium chloride $(\mathrm{NaCl})$ [10]. Besides chlorides, sulfates [11] and/or surfactants [12] could be used. However, high concentration of the stabilizing salts is limiting for most of the applications dealing with incorporation into polymer systems due to their incompatibility with most of the matrices.

Several works dealing with antimicrobial modification of polymers with nisin have been published. However, most 
of the works describe nisin application on plasma activated polymer surface modifier [13] or in matrix of water-soluble polymers $[14,15]$. The thermoplastic incorporation into thermoplastic starch matrix has been also reported [16]. On the other hand, nisin incorporation into the cosmetic compositions is rarely described in the relevant literature.

One of the possibilities for the salt-free nisin stabilization is its attachment via both covalent and noncovalent bonds to polymer chains. PEGylation is typical example involving polyethylene glycol (PEG) [17] that is fully biocompatible polymer from the group of polyethers [18]. PEG is commonly used in medicine, pharmaceutics, and cosmetics [19]. Thus combination of nisin as antibacterial agent and PEG as compatible stabilizer can be suitable for most of the applications introduced above.

Despite the fact that the nisin PEGylation has been known, the detailed study describing the PEGylation effect on nisin time-temperature stability and its comparison with the conventional salt stabilization has not been reported.

This work is focused on comparative study of the longterm stability (up to 165 days) and temperature ( -4 to $55^{\circ} \mathrm{C}$ ) activity of nisin stabilized by both salt and polymer based compounds. In this study, the nisin was experimentally prepared by fermentation of dairy by-product whey and subsequently stabilized sodium chloride, ammonium sulfate, nonionic surfactant (Tween), and PEG. Its long-term stability under various temperatures was studied by means of highperformance liquid chromatography (HPLC), electrophoresis, and microbiological analysis.

\section{Experimental Part}

2.1. Materials. Sweet milk whey was kindly provided by the local dairy research institute (KROMILK, Kromeriz, Czech Republic). Ammonium sulfate $\left(\left(\mathrm{NH}_{4}\right)_{2} \mathrm{SO}_{4}\right)$, sodium chloride $(\mathrm{NaCl})$, sodium hydroxide $(\mathrm{NaOH})$, sodium thiosulfate $\left(\mathrm{Na}_{2} \mathrm{~S}_{2} \mathrm{O}_{3}\right)$, copper(II) sulfate pentahydrate $\left(\mathrm{CuSO}_{4} \cdot 5 \mathrm{H}_{2} \mathrm{O}\right)$, potassium sodium tartrate tetrahydrate $\left(\mathrm{C}_{4} \mathrm{H}_{4} \mathrm{O}_{6} \mathrm{KNa} \cdot 4 \mathrm{H}_{2} \mathrm{O}\right)$, formaldehyde solution, acetic acid, formic acid (85\%), and methanol were purchased from PENTA (Prague, Czech Republic). Tween 80, TRIS Pufferan, Tricine Pufferan, tetramethylethylenediamine (TEMED), sodium dodecyl sulfate (SDS), mercaptoethanol, bromophenol blue Na-salt, and ammonium persulfate (APS) were supplied from P-Lab (Prague, Czech Republic). Polyethylene glycol (PEG) 2050, lactose, trifluoroacetic acid (TFAA), ammonium bicarbonate $\left(\mathrm{NH}_{4} \mathrm{HCO}_{3}\right)$, acrylamide, $\mathrm{N}, \mathrm{N}^{\prime}$ methylene bisacrylamide, Pharmalyte, Coomassie Brilliant Blue R250, glutaraldehyde, molecular weight (MW) and isoelectric focusing (IEF) markers, nisin standard $(2.5 \%$, balance sodium chloride and denatured milk solids), and bovine serum albumin (BSA) were purchased from Sigma-Aldrich (St. Louis, MO, USA). Hydrochloric acid ( $\mathrm{HCl})$, monosodium phosphate $\left(\mathrm{NaH}_{2} \mathrm{PO}_{4}\right)$, dipotassium phosphate $\left(\mathrm{K}_{2} \mathrm{HPO}_{4}\right)$, boric acid $\left(\mathrm{H}_{3} \mathrm{BO}_{3}\right)$, phosphoric acid $\left(\mathrm{H}_{3} \mathrm{PO}_{4}\right)$, silver nitrate $\left(\mathrm{AgNO}_{3}\right)$, ethanol $(96 \%)$, and glycerol were supplied from IPL (Uhersky Brod, Czech Republic). HPLC gradient grade acetonitrile (ACN) was obtained from Chem-Lab (Zedelgem, Belgium). Lactobacillus MRS Broth
TABLE 1: Designation of standard and prepared samples.

\begin{tabular}{lc}
\hline Sample designation & Preparation method \\
\hline NIS-AS & 1 \\
NIS-Tween & 2 \\
NIS-PEG & 3 \\
NIS-NaCl & Commercially available standard \\
\hline
\end{tabular}

(M369) and Mueller Hinton agar (MHA) were purchased from HiMedia (Mumbai, India). All chemicals were of analytical grade and used as received.

A bacteriocin-producing strain Lactococcus lactis subsp. lactis (CCDM 731) was obtained from collection of dairy microorganisms, Laktoflora, Dairy Research Institute, Prague, Czech Republic. A nisin-sensitive strain Staphylococcus aureus (CCM 4516) was acquired from Czech Collection of Microorganisms, Masaryk University in Brno, Czech Republic.

2.2. Sample Preparation. An aliquot (one inoculation loop) of L. lactis subsp. lactis was cultured in $50 \mathrm{ml}$ of MRS broth (media recommended for cultivation of all Lactobacillus species) under anaerobic conditions at $30^{\circ} \mathrm{C}$ for $48 \mathrm{~h}$. This preculture was transferred to milk whey fortified with lactose $(0-200 \mathrm{~g} / \mathrm{l})$ in a $1: 50$ ratio (i.e., $1 \mathrm{ml}$ of preculture to $50 \mathrm{ml}$ of fortified whey) and the medium $\mathrm{pH}$ was raised to 5.5-6.0 with $0.1 \mathrm{M}-\mathrm{NaOH}$. The inoculated medium was incubated for $48 \mathrm{~h}$ at $36^{\circ} \mathrm{C}$ with constant shaking $(245 \mathrm{rpm})$ in laboratory incubator (Incucell 404, BMT a.s., Brno, Czech Republic). The fermentation product was centrifuged (Heraeus Multifuge X1R, Thermo Fisher Scientific Inc., Waltham, MA, USA) for $25 \mathrm{~min}$ at $10^{\circ} \mathrm{C}$ and $15,000 \mathrm{rpm}$ and the supernatant was collected and processed by three different methods. A designation of prepared samples is shown in Table 1.

Method 1: Precipitation with Ammonium Sulfate (AS). A quantity of $\left(\mathrm{NH}_{4}\right)_{2} \mathrm{SO}_{4}(35 \%(\mathrm{w} / \mathrm{v}))$ was added to the supernatant and continuously shaken at $4^{\circ} \mathrm{C}$ in conditioned chamber (Climacell 404, BMT a.s., Brno, Czech Republic) for $18 \mathrm{~h}$. Then the mixture was centrifuged for $25 \mathrm{~min}$ at $10^{\circ} \mathrm{C}$ and $15,000 \mathrm{rpm}$. After that the upper phase was separated and dried using a freeze dryer (ScanVac CoolSafe 110-4 PRO, Lynge, Denmark).

Method 2: Two-Phase Extraction with Tween. The system was prepared by dissolving $1 \%(\mathrm{w} / \mathrm{v})$ Tween 80 and $20 \%$ $(\mathrm{w} / \mathrm{v})\left(\mathrm{NH}_{4}\right)_{2} \mathrm{SO}_{4}$ in the obtained supernatant. Then the mixture was shaken for $30 \mathrm{~min}$ and left to stand for 16 hour. After phase separation the upper phase was separated and lyophilized.

Method 3: Two-Phase Extraction with PEG. First the medium $\mathrm{pH}$ was adjusted to $5.4-6.5$ with $0.1 \mathrm{M}-\mathrm{NaOH}$ and $15 \%$ (w/v) PEG 2050 and 13\% (w/v) $\left(\mathrm{NH}_{4}\right)_{2} \mathrm{SO}_{4}$ were added. The extraction time was $40 \mathrm{~min}$. After that, the mixture was kept for $1 \mathrm{~h}$ at $4^{\circ} \mathrm{C}$ and then the upper phase was separated and lyophilized. 
2.3. Determination of Total Protein Concentration. The total amount of proteins and peptides was evaluated in the liquid phase after fermentation and centrifugation by using the colorimetric method proposed by Bradford [20], with BSA as the standard. The protein contents were determined spectrophotometrically (INFINITE M200Pro NanoQuant, with ELISA reader, Männedorf, Switzerland) at $595 \mathrm{~nm}$.

2.4. Tris-Tricine-Sodium Dodecyl Sulfate-Polyacrylamide Gel Electrophoresis (Tris-Tricine-SDS-PAGE). The polyacrylamide (PAA) gel $(10 \% \mathrm{~T} / 3 \% \mathrm{C})$ as a uniform separating gel and stock solutions (buffers) for Tris-Tricine-SDS-PAGE were prepared according to Schägger and von Jagow [21]. The protein samples were combined with the buffer solution and the mixture was denatured for $5 \mathrm{~min}$ at $80^{\circ} \mathrm{C}$ prior to being loaded to the gel. Electrophoresis was carried out with a constant voltage of $190 \mathrm{~V}$ by using devices Bluestar (Blirt S.A., Dantsic, Poland) and Mini Vertical Dual (Carl Roth GmbH, Karlsruhe, Germany), power supply Consort EV 202 (Consort bvba, Turnhout, Belgium). Finally, the proteins were fixed and stained with Coomassie Brilliant Blue R250 [22] or with $\mathrm{AgNO}_{3}$ (when the protein content in a band was less than $0.5 \mu \mathrm{g})$.

The assumption was that the band corresponding with molecular weight of about $3.5 \mathrm{kDa}$ according to MW marker contains a mixture of nisin A and nisin Z. After electrophoresis, these bands were excised and extracted. A destaining solution consisted of $\mathrm{NH}_{4} \mathrm{HCO}_{3}$ and $\mathrm{ACN}$ (1:1) and an extraction mixture was composed of $5 \%$ formic acid and ACN (1:2). The nisin concentration was then determined according to Bradford [20] and by HPLC. In the case of Bradford method, the calibration curves were constructed by using commercial nisin in the presence of corresponding stabilizing agents (PBS (phosphate buffered saline) for NISAS, Tween 80 for NIS-Tween, and PEG2050 for NIS-PEG samples).

2.5. Reverse Phase High-Performance Liquid Chromatography (RP-HPLC). The nisin concentrations were measured using a HPLC Waters 717 plus Autosampler (Waters GmbH, Praha, Czech Republic) equipped with a dual wavelength UV/Vis detector. A XSelect, C18 CS column $(5 \mu \mathrm{m}, 4.6 \times 250 \mathrm{~mm}$, Waters, Milford, MA, USA) with precolumn Reprosil 100 C18 ( $5 \mu \mathrm{m}, 50 \times 4 \mathrm{~mm}$, Watrex, Prague, Czech Republic) was used. The calibration solutions and samples were prepared by using $0.2 \mathrm{M} \mathrm{HCl}$ and filtered through the syringe filter with pore size $0.45 \mu \mathrm{m}$. The mobile phase was organized as gradient and composed of $0.05 \%(\mathrm{v} / \mathrm{v})$ TFAA in HPLC gradient grade ACN (solvent A) and $0.05 \%(\mathrm{v} / \mathrm{v})$ TFAA in distilled water (solvent B). The gradient consisted of $20 \%$ solvent (A) and $80 \%$ solvent (B) in $0-5 \mathrm{~min}$, of $80 \%$ solvent (A) and $20 \%$ solvent (B) in 6-20 min, and of $80 \%$ solvent (A) and $20 \%$ solvent (B) again in $21-40 \mathrm{~min}$. The injection volume was $25 \mu \mathrm{l}$ and the flow rate was of $0.6 \mathrm{ml} / \mathrm{min}$. The measurement was performed at wavelengths of 200 and $220 \mathrm{~nm}$ (the nisin concentration was calculated from the results of $200 \mathrm{~nm}$ ).

2.6. Agar Diffusion Testing of Antimicrobial Activity. Nisin activity was determined by agar-well diffusion method, using
S. aureus as the indicator microorganism. An aliquot of bacterial culture $\left(10^{8} \mathrm{CFU}\right)$ was applied with a sterile swab on the surface of the Mueller Hinton agar plate. The test samples were prepared in deionized water so that the starting concentration of nisin corresponded to $25 \mu \mathrm{g} / \mathrm{ml}$. Afterwards, the solutions were transferred into the bored wells of $8 \mathrm{~mm}$ in diameter $(250 \mu \mathrm{l} /$ well $)$ and incubated for $24 \mathrm{~h}$ at $35^{\circ} \mathrm{C}$. After incubation, the diameter of inhibition zones was determined as the average of four independent measurements.

2.7. Stability Testing. Prepared samples were assessed for stability during storage for 165 days at $-18^{\circ} \mathrm{C}, 4^{\circ} \mathrm{C}, 25^{\circ} \mathrm{C}$, and $55^{\circ} \mathrm{C}$. The samples were continuously collected and tested by using the Bradford method, RP-HPLC, and agar diffusion assay for determination of nisin activity, as described above. The thermal stability (TS) of the prepared samples was calculated as follows:

$$
\mathrm{TS}(\%)=\frac{\mathrm{NIS}_{t}}{\mathrm{NIS}_{0}} \cdot 100,
$$

where $\mathrm{NIS}_{t}$ is nisin concentration at particular time; $\mathrm{NIS}_{0}$ is starting concentration of nisin.

\section{Results and Discussion}

3.1. Effect of Lactose Content on Nisin Production. An adequate content of carbon substrate is necessary for optimal production of bacteriocin nisin by lactic acid bacteria. Lactose is one of the possible carbon sources in the by-product, whey, comprising a major part of the fermentation media used in this work. In whey, the lactose content usually varies from 4.5 to $6.0 \%[23,24]$.

The effect of fermentation media fortification by lactose on nisin production has been evaluated in many studies. The optimal nisin production was reported when the medium contained $30 \mathrm{~g} / \mathrm{l}$ lactose $[25,26]$. However, the yield of the reaction depends on many factors such as bacterial strains used, fermentation conditions (i.e., temperature, $\mathrm{pH}$, and time), and composition of the media.

In this study, nisin production was examined at various levels of lactose fortification $0-20 \%(\mathrm{w} / \mathrm{v})$. The results are depicted in Figure 1 as dependence of nisin production effectivity, expressed as concentration determined after 48 hours of fermentation. The nisin production was determined by RP-HPLC technique.

It can be seen that nisin intensity production increases with the rising level of fortification up to $4 \%$ of lactose addition. Further lactose addition led to reduction of the nisin biosynthesis due to possible occurrence of competitive processes and elevated osmotic pressure in the fermentation media [27]. Although the lactose concentration of $4 \%$ was found to be the best for nisin production, due to technological and economical aspects (high viscosity of the fermentation media at $4 \mathrm{wt} . \%$ additional lactose content), the whey fortified with 2 wt.\% of lactose was chosen for further nisin experimental preparation.

3.2. Quantitative Analysis of Nisin Content in the Lyophilisates. The lyophilized samples prepared by the methods 1-3 were 
TABLE 2: Determination of nisin concentration in prepared lyophilisates.

\begin{tabular}{lcccc}
\hline Sample & HPLC & \multicolumn{2}{c}{ Electrophoresis + Bradford } \\
& $c_{\mathrm{NIS}}[\mathrm{mg} / \mathrm{g}]$ & {$\left[\times 10^{3} \mathrm{IU} / \mathrm{g}\right]^{*}$} & $c_{\mathrm{NIS}}[\mathrm{mg} / \mathrm{g}]$ & $106 \pm 3$ \\
NIS-AS & $2.3 \pm 0.1$ & $94 \pm 4$ & $2.6 \pm 0.1$ & 1 \\
NIS-Tween & $2.3 \pm 0.2$ & $93 \pm 7$ & $2.7 \pm 0.2$ & $109 \pm 6$ \\
NIS-PEG & $5.3 \pm 0.3$ & $210 \pm 10$ & $5.9 \pm 0.2$ & $234 \pm 6$ \\
\hline
\end{tabular}

${ }^{*} 1 \mathrm{IU}$ of nisin is equivalent to $0.025 \mu \mathrm{g}$ of pure nisin [8].

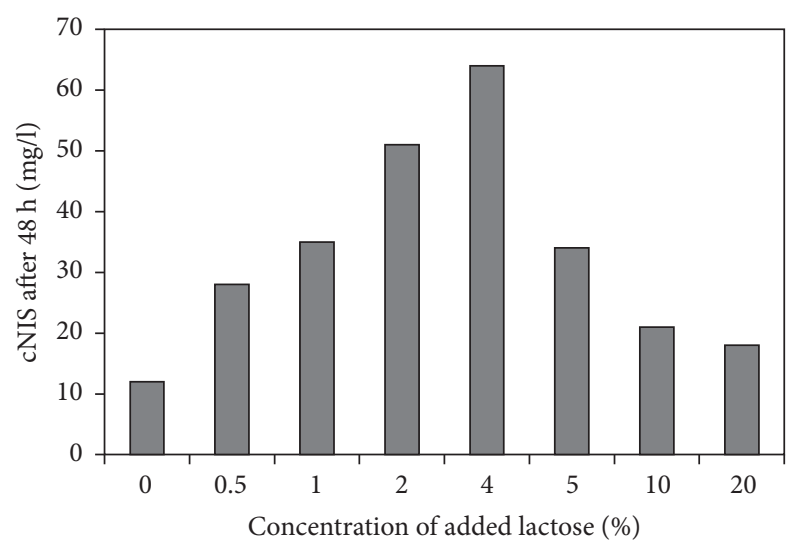

FIGURE 1: Effect of fermentation media fortification with lactose on nisin production after 48 hours of fermentation. Data points are average values of three independent analyses by RP-HPLC. Standard errors were less than $10 \%$.

analysed by HPLC and electrophoresis as indicated above. The results presented in Table 2 show that both methods used in this study (HPLC and electrophoresis) bring comparable results. The nisin content determined by the latter method is about $15 \%$ higher than in the case of HPLC determination that is caused by the different principles of the both techniques. It is caused by the selectivity of both techniques. While HPLC considers only nisin in its A form (due to calibration on commercially available nisin), electrophoresis and subsequent analysis according to Bradford method cover the protein with molecular weight around $3.5 \mathrm{kDa}$, which includes also nisin $\mathrm{Z}$ form [3]. The nisin content in samples stabilized in ammonium sulfate (NIS-AS) and Tween (NISTween) was found to be the same $(2.3 \mathrm{mg} / \mathrm{g}, \mathrm{HPLC})$. On the other hand, the sample stabilized by using polyethylene glycol (NIS-PEG) had significantly higher nisin content, $5.3 \mathrm{mg} / \mathrm{g}$ (determined by HPLC). It was more than 2.3 times higher than in the case of NIS-AS and NIS-Tween.

Since the initial material for nisin extraction was the same for all methods used (i.e., nisin content in the fermentation media was constant), it is clear that extraction step efficiency is the crucial for the nisin content in the resultant samples. The results show that PEG interacts with nisin, which leads to noticeable bacteriocin separation from the fermentation media. The principles of PEG-nisin interactions has been described referring to the ability of formation of proteinpolymer conjugates that can display unique combination of protein and synthetic polymer based material properties [28].
3.3. Testing of Thermal Long-Term Stability. It is known that proteins are sensitive to heat treatment, especially in relation to long-term stability and activity [29]. In this study, thermal stability of nisin products was observed during storage (up to 165 days) at four different temperatures representing conditions of production $\left(-18^{\circ} \mathrm{C}\right.$, lyophilization), storing (4 and $\left.25^{\circ} \mathrm{C}\right)$, and processing $\left(55^{\circ} \mathrm{C}\right)$. The nisin content change in the tested samples stored at various temperatures up to 55 days is shown in Figure 2. It can be noticed that the nisin concentration in all powder samples stored at $-18^{\circ} \mathrm{C}$ changed only negligibly. The storage at $4^{\circ} \mathrm{C}$ caused slight reduction of the nisin content and TS subsequently (9\% NIS-NaCl, $33 \%$ NIS-AS, $18 \%$ NIS-Tween, and 25\% NIS-PEG). On the contrary, storage at $25^{\circ} \mathrm{C}$ led to significant drop in TS values after 55 days. The lowest nisin stability was observed in case of NIS-Tween (87\% reduction) followed by NIS-PEG (71\%), NIS-NaCl (85\%), and NIS-AS (51\%). Nevertheless, TS of the samples NIS-NaCl, NIS-AS, and NIS-PEG is relatively high within the first 15 days of the experiment. All samples stored at $55^{\circ} \mathrm{C}$ underwent steep drop in TS values. In all cases, the reduction of nisin concentration was above $90 \%$ after 55 days. TS of NIS-AS was detected up to 11 days due to low nisin stability in the sample leading to unreproducible results of analysis. In addition, it is worth mentioning that despite the TS of NIS-PEG systems is comparable to other investigated samples, the absolute values of nisin concentration are at least 2.3 times higher (see Table 2) (i.e., absolute concentration of nisin is higher).

In Figure 3, TS values of nisin products determined after electrophoresis-Bradford method (A) and by HPLC (B) after 165 days were compared. Stability loss after 165 days of storage at $-18^{\circ} \mathrm{C}$ was about $5-10 \%$ for all tested samples and at storage at $4^{\circ} \mathrm{C}$ it was about $20 \%$ for samples except for NIS-AS, where TS was about $40 \%$. Significant changes of stability were observed at storage at $25^{\circ} \mathrm{C}$ and $55^{\circ} \mathrm{C}$, where the highest stability was noticed at NIS-PEG $\left(28 \%\right.$ at $25^{\circ} \mathrm{C}$ and $4 \%$ at $55^{\circ} \mathrm{C}$ ) in comparison with other samples including a commercial nisin (NIS-NaCl).

These results are principally in agreement with the work published by Rollema et al. [30] who reported chemical stability of nisin $\mathrm{A}$ at 20,37 , and $75^{\circ} \mathrm{C}$ in various buffers at $\mathrm{pH}$ range from 2 to 8 . The nisin stability after 3 months of storage at $20^{\circ} \mathrm{C}$ resulted in $50-70 \%$ reduction in the bacteriocin content.

3.4. Testing of Nisin Antibacterial Activity in the Lyophilisates. It is known that nisin possesses strong antibacterial activity against Gram-positive bacterial strains [15]. There are two 


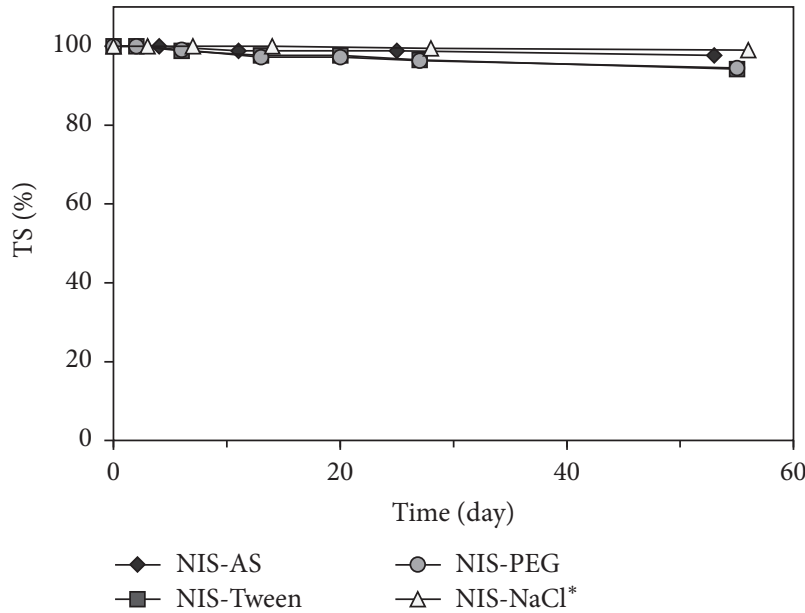

(a)

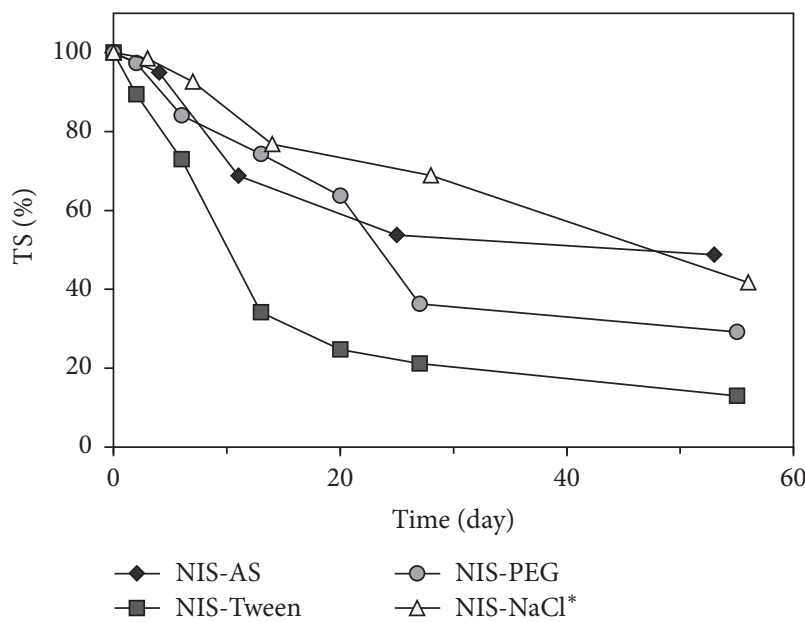

(c)

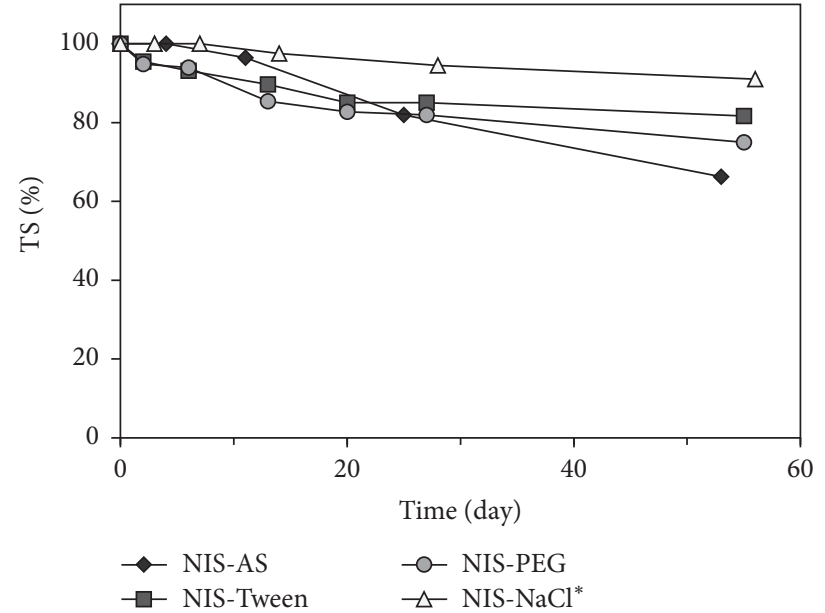

(b)

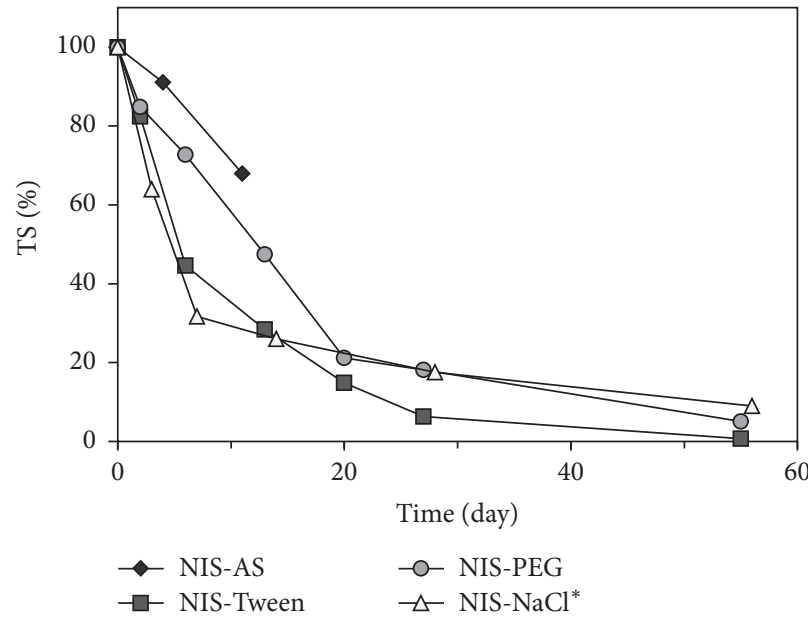

(d)

Figure 2: Thermal stability of nisin (TS) versus storage time at $-18^{\circ} \mathrm{C}(\mathrm{a}), 4^{\circ} \mathrm{C}(\mathrm{b}), 25^{\circ} \mathrm{C}(\mathrm{c})$, and $55^{\circ} \mathrm{C}(\mathrm{d})$. Nisin was determined by $\mathrm{HPLC}$. Data points are average values of three independent analyses. Standard errors were less than $10 \% .{ }^{*}$ Commercial product.

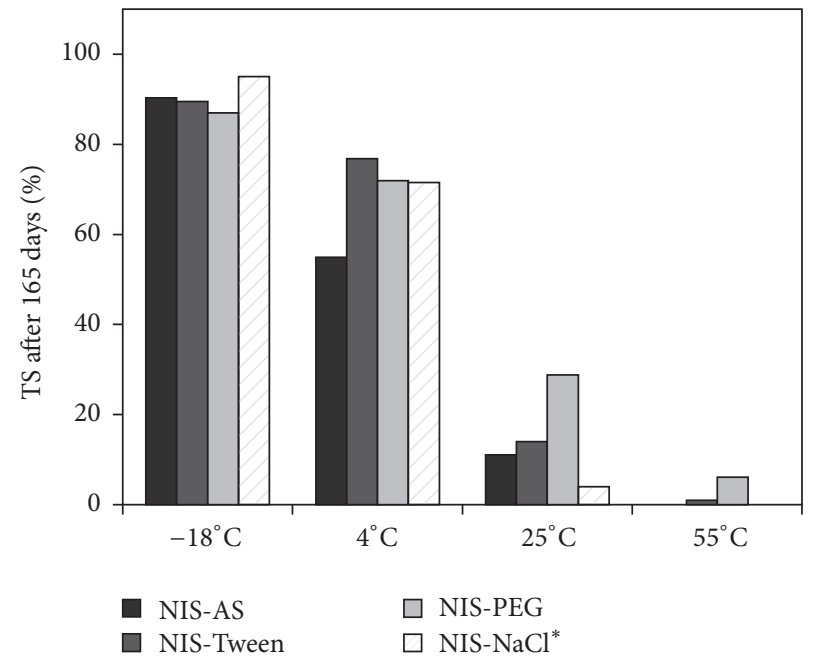

(a)

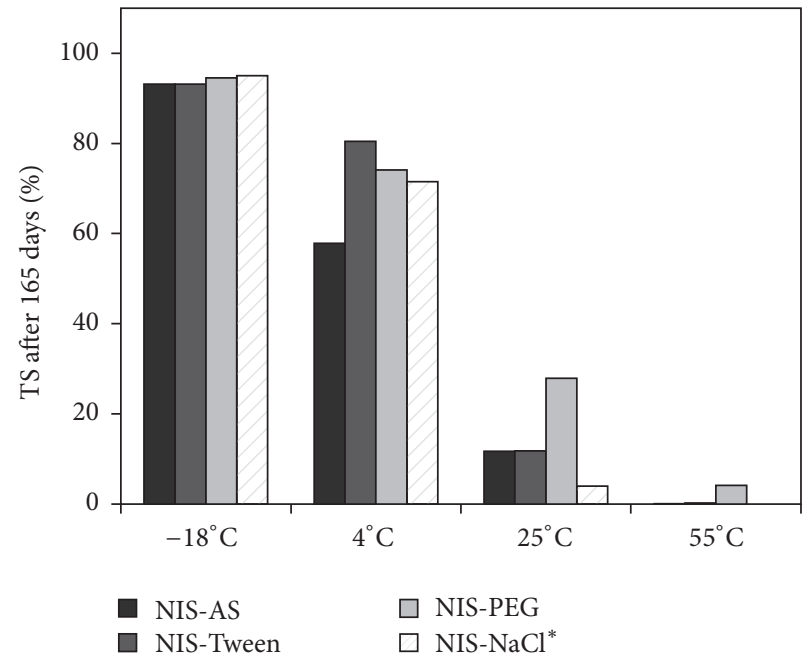

(b)

FIGURE 3: Thermal stability (TS) after 165 days of storage at various temperatures determined by electrophoresis-Bradford method (a) and by HPLC (b). Data points are average values of three independent analyses. Standard errors were less than $10 \%$. ${ }^{*}$ Commercial product. 
TABLE 3: Determination of nisin antibacterial activity on the growth of $S$. aureus by agar-well diffusion method. Data points are average values of three independent analyses.

\begin{tabular}{|c|c|c|c|c|c|}
\hline \multirow{2}{*}{ Storage temperature } & \multirow{2}{*}{ Time [days] } & \multicolumn{4}{|c|}{ Inhibition zone $[\mathrm{mm}]$} \\
\hline & & NIS-AS & NIS-Tween & NIS-PEG & NIS-NaCl ${ }^{*}$ \\
\hline Freshly prepared & 0 & $8.0 \pm 0.2$ & $7.4 \pm 0.5$ & $5.5 \pm 0.5$ & $8.6 \pm 0.5$ \\
\hline \multirow{2}{*}{$-18^{\circ} \mathrm{C}$} & 14 & $8.0 \pm 0.2$ & $7.4 \pm 0.5$ & $5.5 \pm 0.5$ & $8.6 \pm 0.5$ \\
\hline & 165 & $8.0 \pm 0.2$ & $7.4 \pm 0.5$ & $5.5 \pm 0.5$ & $8.6 \pm 0.5$ \\
\hline \multirow{2}{*}{$4^{\circ} \mathrm{C}$} & 14 & $8.0 \pm 0.2$ & $7.4 \pm 0.5$ & $5.5 \pm 0.5$ & $8.6 \pm 0.5$ \\
\hline & 165 & $5.5 \pm 0.5$ & $6.8 \pm 0.5$ & $5.0 \pm 0.2$ & $7.5 \pm 0.5$ \\
\hline \multirow{2}{*}{$25^{\circ} \mathrm{C}$} & 14 & $2.6 \pm 0.5$ & $0.5 \pm 0.5$ & $4.5 \pm 0.5$ & $0.5 \pm 0.5$ \\
\hline & 165 & $0 \pm 0$ & $0.5 \pm 0.5$ & $0.6 \pm 0.5$ & $0 \pm 0$ \\
\hline \multirow{2}{*}{$55^{\circ} \mathrm{C}$} & 14 & $0 \pm 0$ & $1.4 \pm 0.5$ & $4.0 \pm 0.2$ & $0 \pm 0$ \\
\hline & 165 & $0 \pm 0$ & $0 \pm 0$ & $0 \pm 0$ & $0 \pm 0$ \\
\hline
\end{tabular}

${ }^{*}$ Commercial product.

killing mechanisms aiming at the properties of bacterial cell membrane [31]. At lower concentrations, nisin molecule is binding to lipid II, which has a role in correct cell wall synthesis and its blocking that causes the cell death. Moreover, at higher concentrations, nisin-lipid II complex initiates membrane pore formation causing the dissipation of membrane potential and rapid efflux of ions and cytosolic solutes (especially amino acids and nucleosides), leading also to destruction of the cells.

The antibacterial activity of nisin lyophilisates stored at various temperatures $\left(-18,4,25\right.$, and $\left.55^{\circ} \mathrm{C}\right)$ immediately after preparation and after storing for 14 and 165 days by means of inhibition of Staphylococcus aureus bacterial strain is presented in the Table 3. It can be seen that freshly prepared NIS-AS and NIS-Tween showed results comparable with NIS$\mathrm{NaCl}$. On the other hand, inhibition zone diameter of NISPEG was slightly smaller than the others. This result is related to the limited mobility of nisin due to interactions with PEG (discussed above) causing lower diffusion of active substance trough agar media.

The nisin activity of lyophilisates stored at $-18^{\circ} \mathrm{C}$ was not changed even after 165 days. On the contrary, the reduction of antibacterial activity expressed as inhibition zone diameter was observed at temperature above $0^{\circ} \mathrm{C}$. Although changes in the size of the inhibition zones were not observed after 14 days of storage at $4^{\circ} \mathrm{C}$, this temperature after 165 days of treatment caused reduction of antibacterial activity by $31 \%$ at NIS-AS and about $10 \%$ for the other samples. Storage at $25^{\circ} \mathrm{C}$ led to significant drop in antibacterial activity. The lowest antimicrobial stability after 14 days was observed in case of NIS- $\mathrm{NaCl}$ (94\% reduction) followed by NIS-AS (68\%), NIS-Tween (29\%), and NIS-PEG (18\%). Storage at the same temperature after 165 days caused reduction of antibacterial activity above $90 \%$ at NIS-PEG and NIS-Tween and complete loss of activity in the case of NIS-NaCl and NIS-AS samples.

Finally, antibacterial activity of samples stored at $55^{\circ} \mathrm{C}$ was noticed only at NIS-Tween and NIS-PEG after 14 days. In the case of NIS-PEG it was even more than $70 \%$. This result is related to nisin interactions with $\mathrm{PEG}$, that is, interactions with uncommon unsaturated amino acids (dehydroalanine, dehydrobutyrine) or amino and carboxylic groups of amino acids [17].

\section{Conclusions}

Novel method for extraction and stabilization of bacteriocin nisin by using polyethylene glycol (PEG) was described in this study. The product NIS-PEG was compared with commercially available nisin product stabilized by $\mathrm{NaCl}$ and nisin extracted and stabilized by using $\left(\mathrm{NH}_{4}\right)_{2} \mathrm{SO}_{4}$ and polysorbate 80 (Tween).

The results reveal that (i) fortification of whey with lactose is optimal at $4 \mathrm{wt} . \%$ of added lactose; however, $2 \mathrm{wt} . \%$ is convenient due to technological reasons; (ii) quantitative determination of nisin by both analytic techniques used in this work (HPLC, electrophoresis) corresponds to each other; (iii) thermal stability testing of NIS-PEG is comparable with other tested samples; (iv) NIS-PEG product possesses noticeably enhanced long-term stability when stored for 165 days at $25^{\circ} \mathrm{C}$; (v) PEG stabilization is more efficient even for samples stored for 14 days at $55^{\circ} \mathrm{C}$ in comparison with the commercially available product (NIS-NaCl).

The newly introduced method significantly widens application possibilities of nisin as antimicrobial modifier for both hydrophobic and hydrophilic polymer systems.

\section{Conflicts of Interest}

The authors declare that they have no conflicts of interest.

\section{Acknowledgments}

This work was cofinanced by the Ministry of Agriculture of the Czech Republic (Grant no. QJ1310254) and the Ministry of Education, Youth and Sports of the Czech Republic (Grant no. LO1504). Pavlina Holcapkova is grateful to the Internal Grant Agency of Tomas Bata University in Zlin (IGA/CPS/2017/005). 


\section{References}

[1] A. A. de Oliveira Junior, H. G. Silva de Araújo Couto, A. A. T. Barbosa, M. A. G. Carnelossi, and T. R. de Moura, "Stability, antimicrobial activity, and effect of nisin on the physicochemical properties of fruit juices," International Journal of Food Microbiology, vol. 211, pp. 38-43, 2015.

[2] C. Kaletta and K.-D. Entian, "Nisin, a peptide antibiotic: cloning and sequencing of the nisA gene and posttranslational processing of its peptide product," Journal of Bacteriology, vol. 171, no. 3, pp. 1597-1601, 1989.

[3] W. M. De Vos, J. W. M. Mulders, R. J. Siezen, J. Hugenholtz, and O. P. Kuipers, "Properties of nisin $\mathrm{Z}$ and distribution of its gene, nisZ, in Lactococcus lactis," Applied and Environmental Microbiology, vol. 59, no. 1, pp. 213-218, 1993.

[4] T. Zendo, M. Fukao, K. Ueda, T. Higuchi, J. Nakayama, and K. Sonomoto, "Identification of the lantibiotic nisin q, a new natural nisin variant produced by lactococcus lactis 61-14 isolated from a river in japan," Bioscience, Biotechnology, and Biochemistry, vol. 67, no. 7, pp. 1616-1619, 2003.

[5] M. De Kwaadsteniet, K. Ten Doeschate, and L. M. T. Dicks, "Characterization of the structural gene encoding nisin F, a new lantibiotic produced by a Lactococcus lactis subsp. lactis isolate from freshwater catfish (Clarias gariepinus)," Applied and Environmental Microbiology, vol. 74, no. 2, pp. 547-549, 2008.

[6] R. E. Wirawan, N. A. Klesse, R. W. Jack, and J. R. Tagg, "Molecular and genetic characterization of a novel nisin variant produced by Streptococcus uberis," Applied and Environmental Microbiology, vol. 72, no. 2, pp. 1148-1156, 2006.

[7] P. M. O'Connor, E. F. O’Shea, C. M. Guinane et al., "Nisin H is a new nisin variant produced by the gut-derived strain streptococcus hyointestinalis DPC6484," Applied and Environmental Microbiology, vol. 81, no. 12, pp. 3953-3960, 2015.

[8] J. A. Migallon and J. A. Ruseckaite, Lactic Acid: Production, Properties, and Health Effects, Nova Biomedical/Nova Science Publishers, NewYork, NY, USA, 2012.

[9] L. J. de Arauz, A. F. Jozala, P. G. Mazzola, and T. C. Vessoni Penna, "Nisin biotechnological production and application: a review," Trends in Food Science \& Technology, vol. 20, no. 3-4, pp. 146-154, 2009.

[10] L. H. Deegan, P. D. Cotter, C. Hill, and P. Ross, "Bacteriocins: biological tools for bio-preservation and shelf-life extension," International Dairy Journal, vol. 16, no. 9, pp. 1058-1071, 2006.

[11] A. F. Jozala, L. C. De Lencastre Novaes, P. G. Mazzola et al., "Low-cost purification of nisin from milk whey to a highly active product," Food and Bioproducts Processing, vol. 93, pp. 115-121, 2015.

[12] W. S. Kim and N. W. Dunn, "Stabilization of the Lactococcus lactis nisin production transposon as a plasmid," FEMS Microbiology Letters, vol. 146, no. 2, pp. 285-289, 1997.

[13] J. Aveyard, J. W. Bradley, K. McKay et al., "Linker-free covalent immobilization of nisin using atmospheric pressure plasma induced grafting," Journal of Materials Chemistry B, vol. 5, no. 13, pp. 2500-2510, 2017.

[14] M. Hrabalikova, P. Holcapkova, P. Suly, and V. Sedlarik, "Immobilization of bacteriocin nisin into a poly(vinyl alcohol) polymer matrix crosslinked with nontoxic dicarboxylic acid," Journal of Applied Polymer Science, vol. 133, no. 28, Article ID 43674, 2016.

[15] M. Hrabalikova, Immobilization of biologically active compounds in the watersoluble polymer matrix [Dissertation], Tomas Bata University, Zlin, Czech Republic, 2015.
[16] H. M. C. de Azeredo, "Nanocomposites for food packaging applications," Food Research International, vol. 42, no. 9, pp. 1240-1253, 2009.

[17] A. Guiotto, M. Pozzobon, M. Canevari, R. Manganelli, M. Scarin, and F. M. Veronese, "PEGylation of the antimicrobial peptide nisin A: Problems and perspectives," Farmaco, vol. 58, no. 1, pp. 45-50, 2003.

[18] N. A. Alcantar, E. S. Aydil, and J. N. Israelachvili, "Polyethylene glycol-coated biocompatible surfaces," Journal of Biomedical Materials Research Part B: Applied Biomaterials, vol. 51, no. 3, pp. 343-351, 2000.

[19] H.-J. Jang, C. Y. Shin, and K.-B. Kim, "Safety evaluation of polyethylene glycol (PEG) compounds for cosmetic use," Toxicological Research, vol. 31, no. 2, pp. 105-136, 2015.

[20] M. M. Bradford, "A rapid and sensitive method for the quantitation of microgram quantities of protein utilizing the principle of protein dye binding," Analytical Biochemistry, vol. 72, no. 1-2, pp. 248-254, 1976.

[21] H. Schagger and G. von Jagow, "Tricine-sodium dodecyl sulfate-polyacrylamide gel electrophoresis for the separation of proteins in the range from 1 to $100 \mathrm{kDa}$," Analytical Biochemistry, vol. 166, no. 2, pp. 368-379, 1987.

[22] S. R. Haider, H. J. Reid, and B. L. Sharp, "Modification of tricineSDS-PAGE for online and offline analysis of phosphoproteins by ICP-MS," Analytical and Bioanalytical Chemistry, vol. 397, no. 2, pp. 655-664, 2010.

[23] M. Balouiri, M. Sadiki, and S. K. Ibnsouda, "Methods for in vitro evaluating antimicrobial activity: a review," Journal of Pharmaceutical Analysis, vol. 6, no. 2, pp. 71-79, 2016.

[24] J. Cerbulis and H. M. Farrell Jr., "Composition of milks of dairy cattle. I. Protein, lactose, and fat contents and distribution of protein fraction," Journal of Dairy Science, vol. 58, no. 6, pp. 817827, 1975.

[25] C.-I. Cheigh, H.-J. Choi, H. Park et al., "Influence of growth conditions on the production of a nisin-like bacteriocin by Lactococcus lactis subsp. lactis A164 isolated from kimchi," Journal of Biotechnology, vol. 95, no. 3, pp. 225-235, 2002.

[26] X. Liu, Y.-K. Chung, S.-T. Yang, and A. E. Yousef, "Continuous nisin production in laboratory media and whey permeate by immobilized Lactococcus lactis," Process Biochemistry, vol. 40, no. 1, pp. 13-24, 2005.

[27] T. D’Amore, C. J. Panchal, I. Russeil, and G. G. Stewart, “Osmotic pressure effects and intracellular accumulation of ethanol in yeast during fermentation," Journal of Industrial Microbiology and Biotechnology, vol. 2, no. 6, pp. 365-372, 1988.

[28] E. M. Pelegri-Oday, E.-W. Lin, and H. D. Maynard, "Therapeutic protein-polymer conjugates: Advancing beyond pegylation," Journal of the American Chemical Society, vol. 136, no. 41, pp. 14323-14332, 2014.

[29] H. Wang, Y. She, C. Chu et al., "Preparation, antimicrobial and release behaviors of nisin-poly (vinyl alcohol)/wheat gluten/ $\mathrm{ZrO} 2$ nanofibrous membranes," Journal of Materials Science, vol. 50, no. 14, pp. 5068-5078, 2015.

[30] H. S. Rollema, J. W. Metzger, P. Both, O. P. Kuipers, and R. J. Siezen, "Structure and biological activity of chemically modified nisin A species," European Journal of Biochemistry, vol. 241, no. 3, pp. 716-722, 1996.

[31] R. H. Perez, M. T. Perez, and F. B. Elegado, "Bacteriocins from lactic acid bacteria: a review of biosynthesis, mode of action, fermentative production, uses, and prospects," International Journal of Philippine Science and Technology, vol. 8, no. 2, pp. 61-67, 2015. 

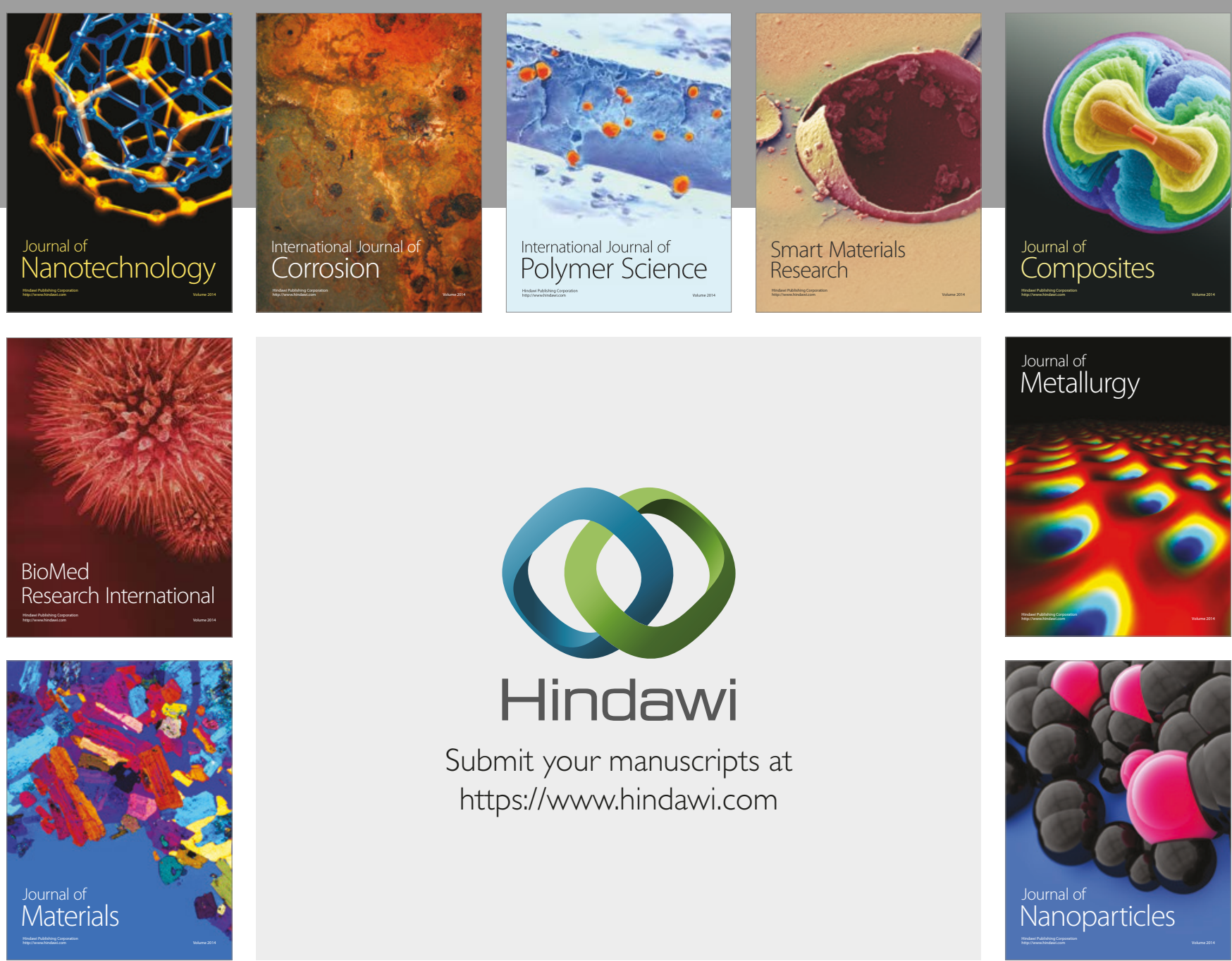

\section{Hindawi}

Submit your manuscripts at

https://www.hindawi.com
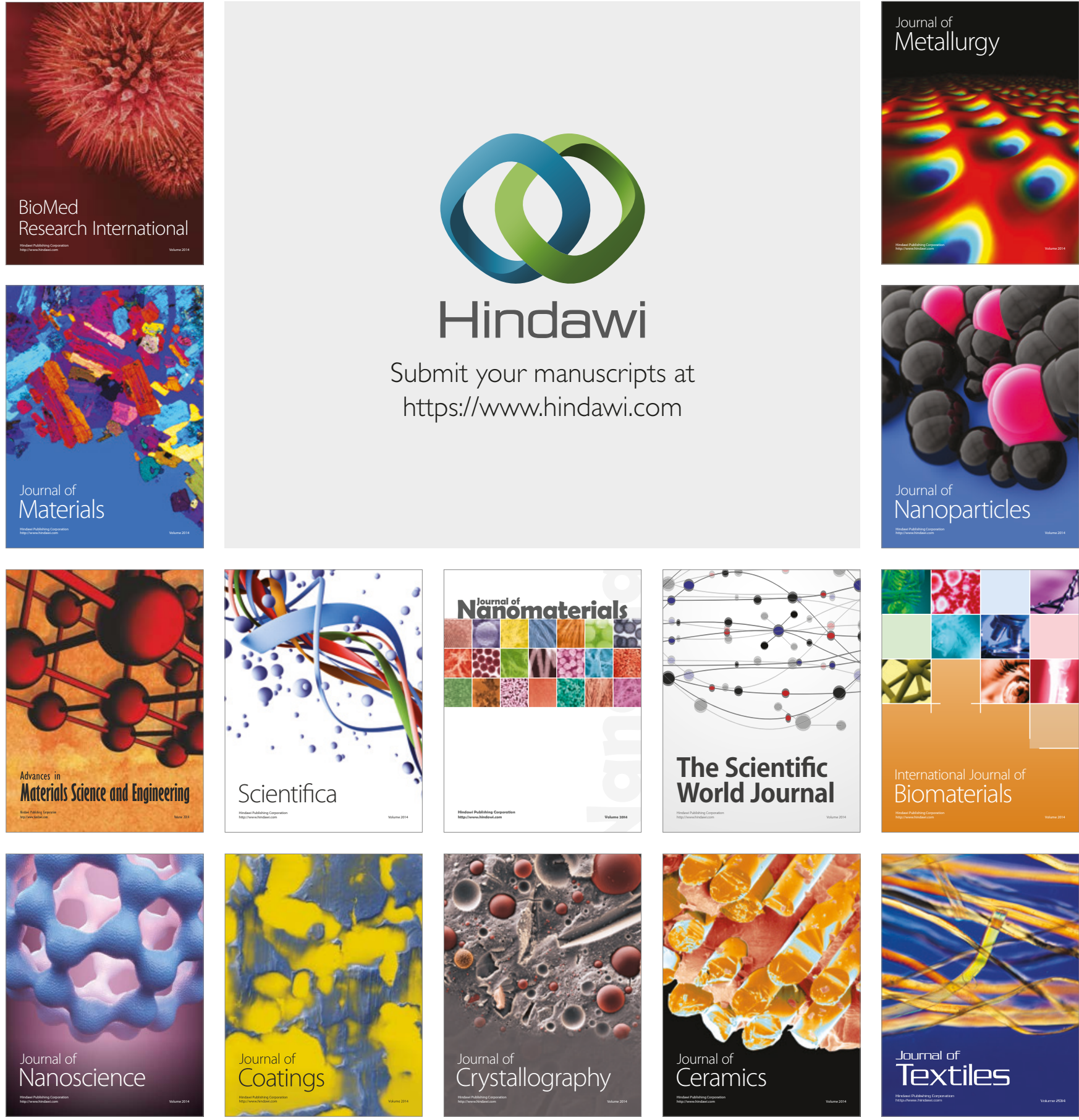

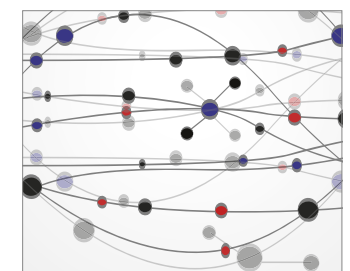

The Scientific World Journal
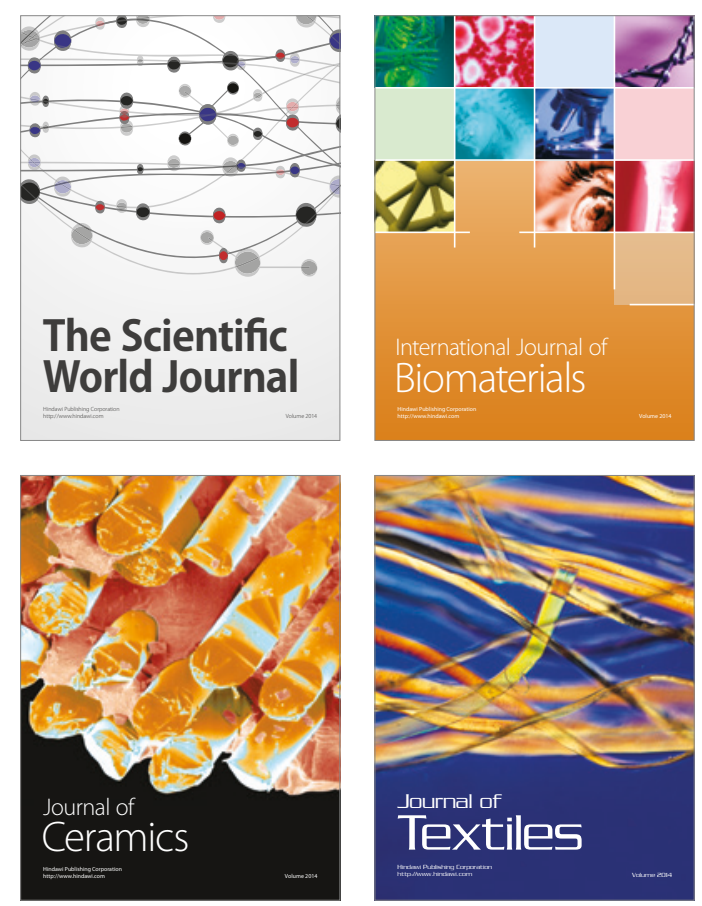